\title{
PENDEKATAN PSIKOLOGI KOMUNITAS DALAM PREVENSI KRISIS KELUARGA
}

\author{
Tina Afiatin \\ Universitas Gadjah Mada
}

\begin{abstract}
INTISARI
Tulisan in bermaksud membahas masalah pember dayaan keluarga dalam membentuk manusia berkualitas dalam masyarakat, khususnya dalam prevensi terjadinya krisis keluarga serta peran psikologi komunitas terhadap masalah tersebut. Menurut penulis, prevensi meliputi intervensi krisis, konsultasi, serta pendidikan kesehatan mental. Dalam intervensi krisis psikolog komunitas dapat bertindak secara langsung atau direktif dengan cara-cara yang efektif dan tepat sementara konsultasi dilakukan dengan berpusat pada program.
\end{abstract}

Kata kunci: psikologi komunitas, prevensi, krisis keluarga.

Tina Afiatin, lahirdi Yogyakarta $1 /$ Februari 1964. Staf pengajar di Fakultas Psikologi UGM dan Fakultas Psikologi Ull. Alumnus Fakultas Psikologi UGM, lulus St tahun 1988 dengan predikat Cum Laude, melanjutkan ke jenjang S2 di tempat yang sama. Saat ini sedang menempuh program Doktor d Fakuitas Psikologi UGM dengan minat khusus pada psikologi klinis. Pengajar dan peneliti ini tertarik pada kajian-kajian masalah remaja, religiusitas dan kemasyarakatan.

\section{PENGANTAR}

$K$ eluarga merupakan dasar unit sosial pade semua kebudayaan dan masyarakat. Corak kehidupan keluarga akan mewarnai kehidupan masyarakat. Di sisi lain dinamika dalam kebuctayaan dan masyaraka! juga akan mempengaruhi kehidupan keluarga. Ada hubungan timbal-balik antara proses kehidupan masyarakat dengan dinamika keluarga. Keadaan keluarga-keluarga yang baik akan mewujudkan kehidupan masyarakat yang baik pula. Perubahan kehidupan masyarakat akan berpengaruh pula pada kehidupan keluarga.

Keluarga merupakan media perantara kehidupan individu dengan lingkungannya. Perubahan kehidupan masyarakat akan mempengaruhi fungsi keluarga yang selanjutnyajuga akan mempengaruhi individu dalam anggota keluarga tersebut. Untuk meng- 
antisipasi dampak perubahan sosial dan masyarakat dalam keluarga, perlu diupayakan usaha-usaha untuk mengurangi dampak tersebut. Usaha-usaha ini disebut sebagai prevensi, yaitu usaha yang bertujuan untuk mengurangi atau mencegah resiko dampak perubahan sosial.

Prevensi merupakan fokus Psikologi komunitas yang dilakukan melalui intervensi sosial dan intervensi komunitas. Korchin (1976) mengemukakan bahwa intervensi komunitas dan intervensi sosial atau intervensi yang berorientasi sistem, sebagai lawan intervensi individual, dapat lebih efektif untuk membuat lembaga sosial seperti keluarga dan sekolah mendapatkan kesehalan mental.

Peran psikolog komunitas, menurut Korchin (1976), adalah mereka harus bekerja di tempal yang dekat dengan orang-orang yang membutuhkannya sehingga bantuan yang diberikan akan lebih efektif; pertolongan harus diberikan kepada semua orang yang membutuhkan, tidak hanya kepada mereka yang mencari bantuan. Psikolog komunitas harus menggunakan sumber-sumber yang ada, di antaranya adalah manusia sumber (key person) di dalam komunitas. Di dalam memberikan bantuan psikolog komunitas perlu melibatkan pembantu-pembantu non-profesional, misalnya ibu-ibu rumah tangga dan mahasiswa yang lelah dibekali pengetahuan tentang kesehatan mental.

Dampak perubahan sosial dalam keluarga akan dapal menimbutkan krisis keluarga. Krisis keluarga adałah keadaan yang sangat menekan dan sangat berkesan yang terjadi di dalam keluarga. Hal ini dapal menjadi sumber gangguan mental. Bentuk-bentuk krisis keluarga antara lain: konflik suamiistri yang memuncak, konflikorang tua-anak yang terus-menerus, perpisahan secara psikologis, dan perceraian.
Krisis keluarga merupakan proses akumulatif dari peristiwa-peristiwa aversif dalam keluarga yang tidak terselesaikan. Untuk mengantisipasi dan mencegah terjadinya krisis keluarga, peran psikolog komunitas untuk melakukan prevensi sangat diperlukan. Berbagai pengetahuan dan ketrampilan psikolog komunitas mengenai prevensi dan masalah yang berkaitan dengan krisis ke. luarga dapat membantu mereka dalam melakukan intervensi sosial dan intervensi komunitas.

\section{PERUBAHAN SOSIAL DAN KRISIS KELUARGA}

Seiring dengan perkembangan zaman, perubahan-perubahan sosial dan masyarakat juga mempengaruhi sistem dan fungsi keluarga. Perubahan-perubahan itu akan membawa konsekuensi, baik akibat positif maupun akibat negatif. Akibal positif bermanfaat bagi kemajuan dan kesejahteraan manusia. Akibal negatit akah menyengsarakan kehidupan manusia dan hal ini perlu diantisipasi, sehingga akibat negatif itu dapat dikurangi atau dicegah.

Salah salu fenomena perubahan sosial yang terjadi akhir-akhir ini adalah meningkalnya peran wanita dalam masyarakat. Pargeseran peran wanita dari peran domestik (domestic role) menuju pada peran publik (public role) menimbulkan akibat, baik yang positif maupun negatit. Akbat positif antara lain: wanita mendapal kesempatan untuk belajar, kesempiatan untuk bekeria punter buka lebar, sehingga wanita dapat pula berperan membantu menambah pendapatan keluarga. Akibat negatif alau merupakan resiko dari perutaahan tersebut antara lain: intensitas wanita sebagai pemelihara dan pengasuh dalam ke'uarga dan rumah langganya menjadi berkurang, karena sebagian waktunya ia gunakan untuk belajar atau bekerja. 
Apabila akibat-akibat negatif dari adanya perubahan sosial ini berkelanjutan, maka hal ini dapat mengganggu fungsi keluarga, terutama dalam hubungan perkawinarı dan dapat menimbulkan gangguan perkawirıar. Gangguan perkawinan menurut, Bloom (1978), dapat merupakan stressor yang menimbukan gangguan fisik dan emosi. Garıgguan perkawinan juga menimbulkan krisis keluarga. Krisis keluarga sebagai suatu stressor perlu diantisipasi untuk mengurarıgi elek stres itu sendiri.

Berbagai cara dapal dilakukan untuk mengurangi efek stes. Thompson (daiam Heller dkk, 1984) mengemukakan strategi untuk mengurangi efek stres, yaitu dengan: (a) memprediksi stressor, yaitu merıgantisipasi kejadian negatif sehingga hal-hal yang negatif atau aversif dapat dikendalikan; (b) memiliki citra-diri untuk dapat mengendalikan hal-ha! negatil dengan merasa bahwa individu memiliki kemampuan dan kekuatani (c) mengontrol situasi, hal ini memungkinkan untuk dapat menentukan akibat darı kejadian-kejadian. Pendapat Thompsorı tersebut merupakan cerminan implikasi intervensi komunitas dalam memandang masalah stres, yaitu memandang penyebab stres adalah dari luar diri individu atau lebih pada penyebab-penyebab sosial, bukan sebab dari dalam diri individu, sedangkan dalarn mengatasi stres lebih menekankan pada langgung jawab internal (pribadi).

Pendekatan psikologi komunitas merupakan alternatıf yang lebih menguntungkan. Hal ini disebabkan karena pendekatan psikologi komunitas memberikan perhatian terhadap proses-proses psikologis umum yang menghubungkan secara konseptua! tingkat kemasyarakatart dan tingkah laku orang. Pengertian tentang hubungarı interaksi masyarakat sosial dan budaya dengan indiviou digunakan sebagai dasar yang rasional bagi program-program untuk mengoptimalkan berfungsinya manusia.

\section{PSIKOLOGI KOMUNIT AS DAN PREVENSI KRISIS KELUARGA}

Dalam bidang kesehatan mental, fokus psikologi komunitas lerutama adalah pada Prevensi, yaitu usaha-Usaha pengurangan resiko gangguan emosi. Menurut Caplan (dalam Heller dkk, 1984) ada tiga macam prevensi, yaitu: (a) prevensi primer, yaitu sekunder, yaitu mengurangi lamanya gangguan mental, dan (c) prevensi tertier, yaitu mengurangi beratnya gangguan mental,

Pappaport (1977) mengemukakarı bahwa prevensi primer dapat berupa interverisi krisis dan melakukan konsultasi. Dalam intervensi krisis, psikolog komunitas dapat bertindak secara langsung atau direktif dengan cara-cara yang elektif dan tepat. Pada keluarga yang sedang mengalami krisis, misalnya: kemalian salah seorang anggota koluarga perpisiahan atau perceraian, maka baniuan petunjuk cara pemecahan masalah ataupun dukungan sosial akan sangat bermanfaat bagi keluarga tersebut. Tujuan intervensi menurut Korchin (1976), adalah (a) mengurangi k:etegangan, kecemasan, kebingungan dan kelidakberdayaarı, (b) mengembalikan orang yang dalam keadaan krisis ke fungsi sebelumnya, (c) membantu orang yang bersangkutan dan keluarganya mempelajari apa yang dapa: dilakukan untuk mengatasi krisis-krisis tersebut dan mengetahui sumber-sumber atau pelayanan df masyarakalt yang dapal membanlu.

Cara prevensi yang lain adalah konsultasi, Konsultasi terhadap krisis keluarga dapat berupa konseling perkawinan. Konseling perkawinan ini merupakan salah satu bentuk dari konseling keluarga (Kahn, 1981). Dalarm lingkup yang lebth luas, hal itu juga meliputi: (a) premarital-counseling, biasanya membantu pasangan yang akan melangsungkan pernikahan dian memberikan bimbingan sera petunjuk persiapan perkawinan dan mernbina hidup perkawinan; (b) predivorce-coun- 
seling. yaitu bantuan yang diberikan pada pasangan yang mengalami kesulitan dalam perkawinan, solusi untuk masalah tersebut dan belajar untuk hidup bersama yang lebih baik atau membuat keputusan untuk bercerai; (c) postdivorce-counseling, yaitu menekankan bantuan pada penyesuaian diri individu untuk hidup sendiri lagi setelah mengalami perceraian, dan (d) general family. counseling, yaitu menekankan pentingnya membina hidup perkawinan dan kehidupan keluarga.

Konsultasi juga dapat dilakukan dengan berpusat pada program. Heller dan Monahan (1977) menyatakan bahwa konsultasi yang berpusat pada program mempunyai potensi terbesar untuk mempengaruhi perubahan komunitas. Tujuan akhir konsultasi yang berpusat pada program adalah untuk memberi keyakinan bahwa komponen mission yang harus dilakukan oleh perantara (agent) itu ditangani secara kompeten. Apabila perantara-perantara itu akan menerapkan program tertentu. maka konsultan (Psikolog Komunitas) memberikan cara-cara pelaksanaan yang terbaik, misalnya: program intervensi kelompok terarah pada remaja untuk pencegahan terjadinya kasus hamil sebelum nikah. Kegiatan ini dapat dilaksanakan di sekolah dengan pemandu guru. Konsultan memberikan modul pelaksanaan nya serta melatih ketrampilan para guru sebagai pemandu diskusi dan nara sumber.

Psikolog komunitas di dalam memberikan bantuan dapat melibatkan pembantupembantu non-profesional. Kerja para psikolog komunitas lebih berbentuk memberi konsultasi daripada langsung memberi pelayanan. Hal ini memiliki tiga keuntungan. Pertama, dapat menanggulangi minimnya psikolog Komunitas. Kedua, dapat 'menjembatani' jarak sosial antara psikolog komunitas dan anggota komunitas yang mungkin memiliki nilai-nilai yang berbeda. Ketiga, bagi para pembantu non-profesional (misal- nya ibu-ibu rumah tangga, mahasiswa) kegiatan layanan pada Komunitas tentang masalah kesehatan mental merupakan kegiatan yang baru serta memperkaya pengalaman. Hal ini dapat membenkan semangat pada mereka untuk melakukan aktivitas ini.

Dalam pendekatan psikologi komunitas, pelaksanaan program prevensi juga dapat dilakukan dengan pendidikan kesehatan mental. Dalam pelaksanaannya, menurut Hellerdkk (1984), program ini dapat dilakukan dengan tiga cara yaitu:

1. Program untuk seluruh komunitas (communnity-wide). Program ini ditujukan untuk seluruh populasi, misalnya program pembinaan keluarga sejahtera, program Bina Keluarga Balita.

2. Program milestone, dalam program ini penduduk pada periode tertentu dari kehidupannya dihadapkan pada program tertentu. Misialnya: pada pasangan yang akan menikah, pada tahun pertama perkawinan, saat menjelang menopause, dan sebagainya.

3. Program resiko tinggi (hight-risk), fokusnya adalah penduduk yang mempunyai resiko tinggi untuk mendapat gangguan mental, misalnya: orang yang baru saja kehilangan pasangan (ditinggal mati atau bercerai), anak-anak dari keluarga yang pecah.

\section{PENUTUP}

Sebagai simpulan uraian ini dapat dikemukakan bahwa psikologi komunitas memberikan peran penting dalam prevensi krisis keluarga. Prevensi krisis keluarga dengan pendekatan psikologi Komunitas dapat dilakukan dengan cara intervensi krisis, konsultasi dan memberikan pendidikan kesehatan mental. Prevensi krisis keluarga merupakan suatu hal yang harus dilakukan untuk mencegah timbulnya gangguan mental akibat krisis keluarga. 
Tantangan yang muncul dalam pelaksanaan pendekatan ini adalah masih sedikit sekali psikolog yang tertarik dengan pendekatan komunitas. Pendekatan ini menuntut kita untuk terlibat secara aktif bagi masyarakat kelas menengah ke bawah atau pinggiran kota pada khususnya. Juga tuntutan untuk mampu menjalin kerja sama baik dengan disiplin ilmu-ilmu lain ataupun aparat pemerintah dan agensi lainnya. Tunt utan kepekaan sosiai, jwa pengabdian dan ketrampitan protesional sebagai psikolog memungkinkan pendekatan yang lebih menyentuh sisi kemanusiaan secara integratif ini akan dapat berkembang lebih lanjut.

\section{DAFTAR PUSTAKA}

Bloom, B.L. 1982. Marital Disruption as a Stressor. Dalam Environmental Influ- ence and Stretegies in Primary Prevention (Donald G. Forgays, Ed). London: University Press of New England.

Heller, K dan Monahan, J. 1977. Psychology and Community change. Homewood, lilionis: The Dorsey Press.

Heller, K: Price, R.H.; Reinharz, $\mathbf{S}$ \& Wardersinan, A. 1984. Psychology and Community Change: Challenger of The Future. Homewood, llinois: The Dorsey Press.

Kahn, M.W. 1981. Basic Methods for Mental Health Practitioners. Cambridge, Massachusetts: Winthrop Publishers, Inc.

Korchin, S.J., 1976. Modern Clinical Psy. chology. New York Basic Books. 